\title{
The Presentation of Hegemonic Masculinity, Parasocial Interaction and Transnational Online Communities: A Case Study of the Turkish Series "Erkenci Kuş"
}

\author{
Hegemonik Erkeklik Temsili, Parasosyal Etkileşim ve Ulusötesi Çevrimiçi \\ (Online) Topluluklar: "Erkenci Kuş" Dizisi Örneği
}

\section{Sharon WILSON * Cihan ERTAN **}

\begin{abstract}
Women in general are still enticed and their consent regarding hegemonic gender relations is being gained by the traditional masculine traits presented and portrayed by the media. This article addresses how the audience of women from a Facebook group create parasocial interaction through the presentation of the hegemonic masculinity of the male character - Can Divit in a Turkish series Erkenci Kuş. Employing a qualitative thematic analysis of 486 posts combined with observations, the authors add an empirical perspective to the widely discussed concept of audience participation and make a claim that the audience perceived motivations for their involvement and their engagement of the show is through the main male character creating what should be known as male objectification. The study doesn't focuses only upon the representation of masculinity, further it also concentrates on the gaze of the audiences, and seeks to illuminate how they (audiences) consume these representations and how they relate themselves to these hegemonic masculine ideals.
\end{abstract}

Keywords: Parasocial Interaction, Facebook, Engagement, Masculinity, Hegemonic Masculinity

Öz: Genelde kadınlar, media tarafindan sunulan ve temsil edilen geleneksel erkeksi özellikler aracılığıyla baştan çıkartılmakta ve hegemonik toplumsal cinsiyet ilişkilerine yönelik rızaları kazanılmaktadır. Bu makale, bir Facebook grubundaki kadın izleyicilerin, Türk dizisi Erkenci Kuş’taki Can Divit karakterinin hegemonik erkeklik temsili üzerinden kurdukları parasosyal etkileşimleri irdelemektedir. Gözlemlerle beraber, 486 gönderinin tematik nitel analizini yaparak yazarlar, yaygın bir biçimde tartışılan izleyici katılımı kavramına ampirik bir perspektif eklemekte ve izleyicilerin, gösteriye katılmak ve dahil olmak için algılanan motivasyonlarının, erkeğin nesneleştirilmesi olarak anlaşılması gereken olguyu yaratan, ana erkek karakter üzerinden gerçekleştiği iddiasını öne sürmektedirler. Çalışma, yalnızca erkekliğin temsili üzerine odaklanmamakta; bunun ötesinde, söz konusu makale, izleyicilerin bakışı üzerine odaklanarak, izler kitlenin bu sunumları nasıl tükettiğini ve söz konusu hegemonik erkeksi ideallerle kendilerini nasıl ilişkilendirdilerini aydınlatmayı hedeflemektedir. Makale ayrıca, hegemonik erkekliğin etki alanına giren, genel anlamda tüm medya kullanıcılarının, özelde ise çevrimiçi toplulukların, tükettikleri metinle kurdukları ilişkilerin analizi bağlamında, parasosyal etkileşimin bir çerçeve olarak nasıl kullanılabileceğine ilişkin metodolojik bir katkı sunmaktadır.

Anahtar Kelimeler: Parasosyal Etkileşim, Facebook, Katılım, Erkeklik, Hegemonik Erkeklik

\footnotetext{
* Assist. Prof. Dr., University Tunku Abdul Rahman, Department of Mass Communication, sharon@utar.edu.my

**Assist. Prof. Dr., Düzce University, Department of Sociology, Düzce. cihanertan1@gmail.com, https://orcid.org/0000-0001-7097-2655
} 


\section{Introduction}

Television shows nowadays are seen as a socialized experience (Jenkins 2006) which with the inclusion of social media, such as Facebook, allows the act of co-viewing as an experience shared by a larger transnational community. In that context, as all the other cultural texts, the relationship of the audience with the media content is not mechanical and unilateral. Therefore the meanings produced by the users are as significant as the messages generated by the media content (Storey 2014), since these meanings produced by the users also contribute to the social reality. This Facebook experience allows users large scale interaction allowing for peer-to-peer and audience communication and participation which is more powerful and more evident (Sutton et al. 2008) than ever before.

Conversations about television series are taking place (Vassalo de Lopes 2009) globally and it is possible to find public or private groups about these shows, fan pages on characters, and behind the scenes videos allowing the audience of television serials in particular to have the ability of watching as they participate in active discussion online. These transnational online communities (Jenkins et al. 2013; Benecchi 2015) have provided fans with a space in which they can connect with each other although there is a physical distance between the actors of these communities of international fan (Hobson 1982; Jenkins 2006; Baym 2007). At the same time, television viewing has also mediated audience response and created a large following while allowing as this study will show these audiences to identify with the media characters.

Parasocial is the term employed to describe a concept referring to the relationships between the consumers of media and the characters in media contents. Thus, parasocial interaction (PSI) points to an interaction occurring during media consumption between a user of it and a character in it. A consumer of media can consider that she really gets to know the character in it if she is in a parasocial interaction with the content (Noble 1975). Thus, a sense occurring is at stake through which the consumer creates a close relationship with the character and his/her personality in the content of media. Therefore over a period of time, through watching a television series, audiences start to think that they actually are acquainted with the characters, as if they are part of their milieu like neighbors or friends. It can also be suggested that, as a result of PSI and the emotions provided through it, viewers hold and maintain motivation to continue seeing the programme (Rubin et al. 1985). Ethnographic studies focusing upon the relationships of viewers with television contents asserted that audiences frequently point to their affection towards characters that results from their sturdy identification with characters (Liebes \& Katz 1990). In previous studies (Alperstein 1991), participants have also described PSI as consuming media content in terms of being transported to another sometimes disorienting world where they become involved in the interactions of those characters who appear in programming and commercials. This experience is also tied to the concept of suspension of disbelief, in which viewers fall out of touch with the real world, and in touch with their imaginary social world. There seems various ways of building a bond for television viewers with media characters (Tian $\&$ Hoffner 2010) from participating in the pain of them, creating affinity, to falling in love with them. Similarly, there has been a trend towards including romantic aspects of parasocial interaction (e.g., Driesmans et al. 2016; Erickson \& Cin 2018), and it is suggested that these romantic parasocial relations are characterized by attractions that are physical, emotional, and sexual (Tukachinsky 2010). Even though there is large body of scholarly work on American television shows (Scaglioni 2006; Benecchi \& Richeri 2013), there hasn't been much work on online communities and Turkish dizi (series) and the hegemonic masculinity of male characters and this apparent gap this study attempts to address. Hence our research highlights hegemonic masculinity in the context of a media character in a Turkish series entitled 'Erkenci Kuş' (EK) as instructive for understand the groundings of parasocial interaction and the relatedness 
towards the research in question. Nevertheless, the argument that we are making in this paper is the fact that the development of parasocial interaction is built upon the hegemonic masculinity of the media character.

\section{Representation of Masculinities in Turkish Television Series}

It can be suggested that the representation of masculinity in Turkish television series has changed over a historical period, depending upon the political, economic and social context. Thus, it cannot be claimed that there is one culturally idealized masculinity that exists in Turkish television series, rather different forms of masculinity can be found that contradict each other. From relatively modest masculine characters to hyper masculine and violence prone characters may be found in Turkish series. As Yücel $(2014,96)$ suggested, the constitution of masculinity in the Turkish media revolves around various paths such as: heroes being in desperate straits, characters who are always good or always bad, who are seeking to climb the social ladder, and around themes related to family, mother, honor, violence, and crime.

Within the historical process, while traditional form of masculinity which is both physically and behaviorally the "hard male type" was dominant until the 1980's, after the 1980's and in the early 1990's it can be seen that there is a transition from the traditional representation into more emotional and more contemporary types of masculinity in Turkish television (Gürkan \& Serttaş 2017 , 404). From the 1990's to the 2000's, it can be asserted that the representation of masculinity in Turkish series has shifted from, so to speak, its modest form into more pretentious, wealthy, well - groomed, violent, and powerful (in every aspect) forms, at least in regard to the starring characters. However, it should be considered that the historicity of masculinity within Turkish series cannot be regarded as a linear process in which only one type of representation of masculinity would exist in a given period. Yet, it can still be argued that there are remarkable shifts in these representations, in terms of the forms of masculinity mentioned above.

The hegemonic form of masculinity is being constituted not only by itself but by relation to other masculinities and women. In addition, hegemonic masculinity, as discussed in the following section, is constituted within cultural processes rather than through oppression. Therefore, it is also true concerning the representation of culturally idealized masculinity in television series which is why it is crucial to take into consideration the ways through which masculine characters are being represented, especially in relation to women.

A recent research concerning gender equality in television series in Turkey which analyzed 12 Turkish series indicates the differences between women and men in terms of gender representation. According to the study, of 12 television series 7 have a story centered around men in relation to the themes of war, violence, mafia, crime, terror, and militarism. While the way of representing women in the series depends upon sentimentality, maternal, courtesy, and charming; men are predominantly represented as rough, tough, competitive, and extrovert (İnceoğlu \& Akçalı 2018). As mentioned before, although there are masculinities, rather than a single masculinity represented in television series; however, the other represented masculinities through which hegemonic masculinity constitutes itself are being melted and tamed in the hegemonic form of masculinity. The long-standing hegemony of the alpha male has been unrivaled by any other romance hero to date. Wild, passionate, and autocratic, the alpha hero "embodies patriarchal power in all its glory" (Frantz 2009, n.p.). He is "powerful, domineering, arrogant, immensely wealthy and endowed with rugged good looks" (Bach 1997, 28). The alpha hero should demonstrate his masculinity and be the man in the novel who is the strongest biologically and fittest esthetically. The spectacular virile body is the signifier of the power of him. (Perez-Gil 2019, 171).

In a general sense, even if it is quite difficult, due especially to the abundance of the 
television content generated, to determine the way the hegemonic form of masculinity is being presented in Turkish series, it can be suggested that there is a hybrid representation of masculinity combining the traditional and the contemporary attributions at once that constitutes so-to-speak the neo-liberal hegemonic masculinity.

\section{Thinking Masculinity Within Media Content Through Hegemonic Masculinity}

The reality of the mundane can be comprehended, as Berger and Luckmann (1991, 35) suggested, as a reality which has its own order, being constituted inter-subjectively, and being objectified by the language and interactions between individuals. It is this language that "provides me with necessary objectifications and posits the order within which these make sense and within which everyday life has meaning for me" (Berger \& Luckmann 1991, 35-36). From the seminal point of view of Berger and Luckmann (1991), it can be suggested that all kind of social relations are part of that language, and, in that context, the contents generated by the media have great significance in constituting the social reality related to diverse parts of society.

The media, as one of the significant tools and components for the regime of truth in which social realties are being constituted highly virtually by citing, at the same time, to physical reality (Ergur 2016), have a non-negligible role in constituting social reality in terms of gender relations by conveying its visual and aural contents to the consumers. In that context, the representation of masculinity is crucial regarding the gender regime in a society which constitutes the social formations of masculinity concerning hegemonic and subordinated ones. As Connell (1992) suggested, there are different masculinities and representations of men not only across cultures but also within a given culture. However, these differences should not be understood solely as lifestyle diversities since different masculinities are being constructed regarding other masculinities; hence some versions of masculinity are being placed in a position of hegemony, while others are being marginalized (Connell 1992). Hegemonic forms of masculinity, that's to say hegemonic masculinity, is being socially constructed within the cultural process by some cultural agents, institutions such as religious officials, journalists, advertisers, politicians, playwrights, academics, sportsmen etc. (Donaldson 1993; Connell \& Messerschmidt 2005). These agents hold the power of defining the culturally affirmed masculine ideals and regulate the gender regime in a given society. In that context, the media representation of hegemonic masculinity contributes to constituting objectified social reality regarding the gender regime of a society.

It should be noted that masculine forms can be varied according to the social and historical context in which it emerges which is the main characteristic of the Gramscian term "hegemony". In that sense, "hegemony" is being used to refer to the dynamics of the structure of power, to understand the power shifts, and resistance to the existing social structure (Connell \& Messerschmidt 2005). That is to say, the characteristics of hegemonic masculinity and the dominant cultural masculine preferences can be different in different periods of time (Kimmel 1994). Yet, it can be suggested that culturally idealized form of masculinity is, on the one hand, exclusive, hierarchically organized, brutal, violent, tough, rich, heterosexual, socially sustained; on the other hand, it is anxiety - provoking, contradictory, and crisis - prone (Donaldson 1993). It should also be pointed that hegemonic masculinity is an ideal type in Weberian sense, it is the abstract category which helps to define/understand the gender relations between/among different masculinities and femininities. As are all ideal types, as Connell suggested (2005), the majority of men may not conform to it but may be in collaboration with its ideals in order to take advantage of being in the dominant position of men in society (Neville 2009, 235).

As Connell and Messerschmidt suggested (2005), the embodiment of masculinity has a 
great significance within the gender regime which means that bodily traits would determine the position of a man or a woman in the gender hierarchy. In that context, being a 'real' man requires adopting the particular ways of having a masculine body. The demonstration of masculinity through bodily performances and sport is essential for constructing a masculine identity; the body becomes a surface on which men have control, authority, discipline that are also associated with masculinity (Gill et al. 2005). According to Connell (2005, 54-56), not only the bodily performance itself but also the exhibition of the performance is crucial so as to construct and maintain masculinity:

"The constitution of masculinity through bodily performance means that gender is vulnerable when the performance cannot be sustained... The body ... is inescapable in the construction of masculinity; but what is inescapable is not fixed".

These bodily ideals concerning masculinity, especially in a consumer society in which the media and visuality occupy culturally significant position, are being constructed by television programs, magazines, films, advertisements etc. However, the representation of masculinity through the body in media is not a fixed character, so that different masculinities constituted by different bodily traits can be found. What is problematic is how those diverse body traits are related to each other; and how this process contributes to the construction of hegemonic masculinity. Hegemonic masculinity in this context is seen as a form of masculine character that has been culturally idealized, a pattern of masculinity celebrated and exalted by role models (Carrigan et al. 1985; Connell 1990). According to Araüna et al. $(2018,86)$ a particular model of masculinity is thus constructed within media representations which define the right ways of being a man (Hanke 1998) and play a significant role in turning the "normative" into the "normal" (Kimmel 1993). Placing women in an inferior position, othering of gay men, the associating of masculinity with being tough and competitive are the prominent characteristics of hegemonic masculinity in a contemporary world (Connell 1990). The set of idealized standards for men includes courage, strength, emotional stability and rationality, as well as the continuous preoccupation of proving gender to others (Coston \& Kimmel 2012). The exaltation of hegemonic masculinity is the way in which the gender order is stabilized (Connell 1990) and the reason why gender operates as a mechanism of marginalization (Coston \& Kimmel 2012).

Hegemonic masculinity as a theoretical concept is being employed in media studies in order to map the relations between different masculinities. However, it should be noted that it implies the dynamic nature of gender relations and thus it is not a fixed character type (Connell 2005). Thus, media representations of masculinity may be varied; different and controversial masculinities can be involved by media instruments. Despite this controversy, there might be culturally dominant ideals of masculinity that circulate within cultural texts consumed by people. As Hall suggested (2005), messages are the production of television defining and constructing meanings, assumptions and knowledge that being inherently dominant and hegemonic. However, it doesn't constitute a solely closed system and doesn't necessarily guarantee or determine the reception of the audiences, which means that the meanings produced by the receivers of the television content might either be in cooperation with hegemonic messages or that the meanings of the receivers can also be contradictory to the dominant messages produced by the media. Briefly, although media encodes the information revolving around the dominant and hegemonic discourse audiences can still hold a position to decode the messages in a contrary way or vice versa. Therefore, the importance of this study is that it doesn't rely in its focus upon the representation of masculinity; rather its importance stems from the fact that it also takes the gaze of the audiences into account and seeks to illuminate how they (audiences) consume these representations and how they relate themselves to these hegemonic masculine ideals. 


\section{Turkish Television Series}

Turkey in fact, in a few years, has developed from nothing to the world's second largest exporter of television dramas after the US. According to the Istanbul Chamber of Commerce revenue from overseas sales of television shows surpassed $\$ 350$ million in October 2016. It was $\$ 10,000$ in 2004. Executives at MIPCOM, where the world's television industry gathers, estimates the market will pass its target of $\$ 1$ billion from exports by 2023 . The study also shows audiences in nearly 100 countries watch Turkish television dramas and Turkey ranks after the U.S. as second in the world in drama export with $\$ 350$ million in revenue. In recent years, Latin American countries in particular watch Turkish soap operas, which are among the top 15 programs in those countries. Overtaking the place of the countries like Brazil and Mexico, whose soap operas were very popular in the past, Turkey now exports television dramas to these countries (Irani 2017).

According to the statistics provided by Turkey Statistical Institute (TUIK), in Turkey, within the domain of cultural activities, people give $91 \%$ of their time in order to consume audio visual media and $87 \%$ of that time is being portioned for watching television (available on http://www.turkstat.gov.tr/PreIstatistikTablo.do?istab_id=1252, accessed on 21 October 2018). Television dramas, including soap operas in which personal and domestic narratives are frequently the central part of storylines, dramatize personal life, over and above questions of power, politics, economics, social structure, religion, science or ethics (Carroll 1996; Creeber 2001). These customized storylines touch on shared human pastimes and experiences which anyone can pick out within his or her daily life, experiences and understanding (Giles, 2002). It may additionally permit audiences to experience that they are collaborating in a real story which is taking place just next to them, empathizing with the characters and caring about what happens to them (Carroll 1996; Creeber 2001; Kincaid 2002; Hobson 2003). To a greater extent, major aspects of television drama series such as, "intimacy" and "continuity" or "serialization", engender a deeper degree of audience engagement and eventually becoming identifiable, empathetic and discursive to mass audiences (Newcomb 1974; Valaskivi 2000). Through this process of personal engagement in the consumption of television series, associated with familiarity, empathy, identification and reflection, greater personalized symbolic meanings are allowed to the beholders of the gaze (Riley et al. 1998).

\section{Methods}

This study made use of qualitative research, particularly descriptive textual analysis from an inductive reasoning approach, moving from specific observations to broader generalizations and theories. In inductive reasoning, we begin with specific observations and measures, begin to detect patterns and regularities, formulate some tentative hypotheses that we can explore, and finally end up developing some general conclusions or theories. Inductive reasoning, by its very nature, is more open-ended and exploratory, especially at the beginning. The following are some of the purposes underlying the development of the general inductive approach. These purposes are similar to other qualitative analysis approaches. 1. To condense extensive and varied raw text data into a brief, summary format. 2. To establish clear links between the research objectives and the summary findings derived from the raw data and to ensure these links are both transparent (able to be demonstrated to others) and defensible (justifiable given the objectives of the research). 3. To develop of a model or theory about the underlying structure of experiences or processes which are evident in the text (raw data) (Thomas 2006). The case study, as Cresswell (2014: 95) suggested, is an inquiry design that can be utilized in order to focus on TV contents, events, and processes. Therefore, the case study is considered by researchers, apart from the thematic analysis which is discussed below, as one of the convenient 
methodological tools this article relied upon in order to analyze the series at stake. The article is organized around these methodological stances, and the research questions of the study were determined as follows:

1. How is the main male character being represented in the series (EK)?

2. How can the representation of the male character be considered in regard to hegemonic masculinity?

3. How do women audiences in closed Facebook group about the series (EK) read this represented masculinity by way of the parasocial interaction they build with the male character?

\section{Case Study}

The article is based on the case study of television romantic comedy drama Erkenci Kuş (EK). This series is about a young ordinary woman Sanem from a working middle class family who works in her father's bakkal (grocery store). From Episode (Ep) 1 the audience sees Sanem (heroine) being forced to get a full time job by her family or face the consequence of being married off. She then takes on employment in an advertising company Fikri Harika where her sister Leyla works. In Ep2 she finds herself in a difficult situation where she is required to betray the trust of her boss Can Divit by his brother Emre Divit. Eventually in Ep10 onwards romance develops between Sanem and Can and from Ep16, the series revolves around the internal conflict of the characters in developing their relationship while intertwining with the lives of the other characters on the show.

\section{Platform, Sample and Data Selection}

We began with participant observation, as this is the first step in ethnographic studies. (Schensul \& LeCompte 1999, 91). Participant observation was considered critical in defining and directing relationships with informants, helping the researcher to gain a sense of how things are structured and prioritized, how people interrelate, and what the cultural criteria are, showing the researchers what the participants consider important in terms of etiquette, leadership, politics, social interaction, and taboos, and helping the researchers to become more active.

We decided on the Facebook closed group page 'Erkenci Kuş for English Speakers' as our aggregated search engine of choice, since it is limited to every member who has ever commented on the page and limited any outsiders from commenting as well. All messages were selected for analysis regardless of who wrote them, when they were written or any other considerations (Zrebiec \& Jacobson 2001; Armstrong et al. 2012). By including all participants and messages in the analysis, it ensures that the results will be representative of all group members (Smedley \& Coulson 2018, 12). The purpose of this information is to aid in creating the data set, and eventually later, offer more dimensions for our analysis of the thematic map. Using three different search terms - Can, Can Divit, Canem - the resulting data corpus consisted of 486 articles from September 30, 2018 April 5, 2019, eliminating all irrelevant sets including the verb 'can' with no relevance to the criteria set. In the next step, these articles were analyzed for inclusion into the data set allowing concepts and ideas to merge naturally. The researchers consider that an individual's desire to participate in an online community is a result of the said individual determinant (e.g., positive anticipated emotions and desires) and community influences (e.g., social identity). The researchers also consider that some individuals known as 'lurkers' may not decide to actively participate in online communities. Instead, rather than engaging with other users online, they may decide to unobtrusively read, but not write about their consumption interests (Bagozzi \& Dholakia 2002). Permission was sought and granted by the participants of the online closed group. 


\section{Thematic analysis}

This research is based on the thematic analysis methodology (Braun \& Clarke 2006; Aronson 1994). This is a method of analyzing data by identifying patterns and organizing them into themes. The thematic analysis process as described by Braun and Clarke (2006), is simplified and includes the gathering of all relevant content within a specific time frame pertaining to the research study.

This raw data constitutes the data corpus and relevance, and all invalid or irrelevant content is weeded out. The remaining data is the data set and from here initial codes are derived and categorized. "Codes identify a feature of the data (semantic content or latent) that appears interesting to the analyst..." (Braun \& Clarke 2006, 18). This coding allows the researchers to organize the data into meaningful groups. In terms of the generic inductive approach, Thomas (2006, p. 242) argues that the data analysis procedure is to develop categories into a framework or a model. This framework can summarize the raw data and convey key themes or processes. These categories are developed from the coding.

This strategy has five steps: initial reading of text data, identification of specific text segments relating to the objectives, labelling the segments of the text to create categories, reducing overlap and redundancy among the categories, and creating a model incorporating the most important categories (Liu 2016, 132). This approach is particularly useful for describing and organizing data in accord with a pre-determined theoretical framework of parasocial interactions mentioned above.

We first familiarized ourselves with the sample data and independently generated initial lists of theme codes. We then compared our lists, discussed differences, and settled upon an initial set of codes to use when tagging the sampled data elements. In addition, we agreed each researcher could add codes to the list, and we would later discuss these additions. Next, we each independently reviewed each of the sample data elements and inspected any photos or videos included in the post to discern meaning. The researchers manually classified and analyzed such text data. Out of 1,830 available Facebook posts, 486 posts were subjected to analysis after the removal of miscellaneous posts which included redundancies and posts with no comment or text. We then tagged it with up to 5 theme codes believed to be relevant to the post. We compared our updated lists of theme codes, resolved differences, and discussed the processes we each employed. During the early course of those discussions, we agreed to shift away from applying a strictly semantic lens (word meaning) when analyzing the data elements and toward a more interpretive lens (statement intent). This was necessary, as intent was not always clearly conveyed in just the post text. An interpretive lens was necessary to induce meaning from the visuals, which ultimately resulted in coding the post as both visuals and text. We made several iterations through the entire sample. Once we reached consensus on the final set of codes and coding of all data elements, we developed names and definitions for each theme code. We then spent time analyzing the individual theme codes to identify similarities in purpose and intent to group the codes into theme content categories and subcategories. Finally, we used that information to develop our thematic web of content. Over the course of several months and using the theme categories and subcategories identified we each independently reviewed and tagged each data element in the new sample with up to 6 theme codes deemed to be the most relevant to the post intent based on the literature reviewed.

Thus, through an examination of participants' Facebook text messages, discursive practices, and the broader social context in which Facebook interaction unfolds, the negotiation and hidden manifestation of usage was grasped (Rambe 2012,299) specifically posing the following question to identify (1) the parasocial interaction as prescribed by the literature (2) the masculine traits identified which results in the interaction. 


\section{Results}

The Facebook closed group was called 'Erkenci Kuş for English Speakers' hence the conversations amongst participants were held in English which is natural. The group was formed on $11^{\text {th }}$ June 2018 before the first episode was aired. As of the $23^{\text {rd }}$ episode of this series there were 19,368 members, not all of which were active participants on this group. Many users who were out of the country or did not live in Turkey watched the series via Canli television live streaming on YouTube and eventually watched the show with English subtitles after the show was translated. A number of links were also passed on by the participants during the exchange of content. A 'watch live' viewing party was also created weekly in the group to encourage participants to view the show live and comment. Based on observation, the live stream of the show attracted an average of 75,000 views worldwide, which started only from ep10. From the observation it was found that participants found great pleasure in viewing this show, social relations were created around a common content and participants were obsessed with the main male character of Can Divit. There were also free expression of opinions and criticisms allowing to define the fate of the plot and participants suggestions of plot development was somehow suggested to the producers, scriptwriters, building opportunities for new stories.

\section{Descriptive Analysis}

\section{Male Character 'Can Divit' and Masculinity}

The textual and visual analysis of the episodes indicate, the character Can Divit is presented as a model of hyper masculinity marked by aggression, strength, dominance and competitive drive. The construction of this character tends to uphold sex-role and trait stereotyping and refers to realities or characteristics such as behaviors, beliefs and actions that are exceptionally masculine in nature (Wober \& Gunther 1988; Ricciardelli et al. 2013, 119). He is accepted to be physically powerful with the musculature acting as a signifier of strength, power, control, inflated presentations of toughness, heterosexuality and a focus on sports, cars and fighting (Morgan 1993; Ricciardelli et al. 2013, 119). He is also seen to accentuate the dominant position of men in society which present us with the hegemonic ideal of the productive, self-sufficient, rational and relational issues in the context of power dynamics and interactional presentations. This traditional masculinity is defined by such characteristics as independence, sociability, proficiency, competitiveness, and dominance (Winstead \& Delege 1993). Media representations of this character played a role in reinforcing ideas about what it means to be a "real" man in society. He is depicted as athletic - playing football (ep5), weight lifting (ep23), boxing (ep8), and an adventure seeker - white water rafting (ep1) and portrayal of chopping wood (ep5). He is the CEO of Fikri Harika, an advertising company and is known to all as 'patron' (boss) and therefore able to make decisions, solve problems and in this capacity network with international businessmen (ep4, ep18, ep20) and therefore able to speak multiple languages (ep4). He is financially independent and this is through the ownership of his own house and cabin in the woods (ep4) and vehicles such as a truck and motorcycle (ep1,ep2). He is also portrayed as able to bond with other male characters over alcohol and conversations about girls (ep13) and is rewarded for self-control and the control of others (ep5), aggression and violence (ep7), and physical desirability - bare chested (ep2), in a towel (ep19), in workout gear (ep22).

As mentioned by Earp, Katz and Katz (1999) and concurred with from this study, the media's portrayal of men tends to reinforce men's social dominance, the majority of male characters in the media are heterosexual and more often associated with the public sphere of work, rather than the private sphere of the home, and issues and problems related to work are 
more significant than personal issues. This is seen through Can Divit's decision to sell his own home to raise funds to ensure the advertising company stays afloat during difficult times (ep22). His dominance over other female characters such as his co-star Sanem can be seen in the depiction of him grabbing her arm and telling her that "your scent only belongs to me" (ep20). In this context it is clear through the traits of the main character and his interactions with all other characters, Cey Cey, Leyla, Emre, Aylin, Deren, Gulitz, Pollen etc. in the show that men could benefit from patriarchal privilege without personally being engaged in direct acts of aggression or the oppression of women. These exists a compromise with women rather than exercising upfront domination or contested displays of authority.

Masculinity in this sense is highly desired as is establishing oneself within one's community or society is central to "being a man". What is evident is the fact that the parasocial interaction created the basis for 'female gaze' through the hegemonic masculinity of the attributes of the character Can Divit. The clichéd representation of masculinity have in fact attracted female viewers to the show and infinitely launched a parasocial interaction with Can Divit and continuous discussion with other members of this online community. This created a certain connectivity between users of the group and a like mindedness for the show and the character.

The study brought about five main themes which were attributes frequently mentioned by the online community posts including mental attractiveness, (imagined) physical attractiveness, and perceived similarity between user and television character, (imagined) interaction with the character, sexual attraction and perceiving the character as a friend These themes tie both parasocial interaction and hegemonic masculinity in a symbiotic and cyclical manner which contributes to the audience reaction, interaction and engagement.

\section{Mental Attractiveness}

The users were attracted by the characters mental simulation and at some points they were relating the character with the actual person.

P3: Can Divit considered himself an educated man. Not just a smart man. He understood quite well the difference between knowledge and the use of that knowledge. He understood the difference between possess...

P3:I can't get over of him...he always kill me inside and out with his masculine body and smile. I love the way he is...

P4: Is just one package, what a girl ever wants in her life

P13:He is clear headed, decisive, and creative-minded. His best characteristic is that he doesn't judge anyone on the basis of financial status and past actions... Seems like he only ever needed to be tethered to his soulmate to actually deal with a disaster and learn to forgive others.

\section{Physical Attractiveness}

The physical attributes of the media character seem to be a source of attraction for the users. The more masculine he was, the more they anticipated an interest for him. The users were surprisingly attracted to all the traditional facets of masculinity as prescribed by the literature.

P18: He's smile, he's eyes..body you name it he's got it!!

P21: I like the fact that he is manly, rugged, romantic when he wants to be, he isn't a womanizer, he only goes after one girl, the one who catches his eye (Sanem)...

P15:I agree, we all love Can for his looks...

Physical attractiveness, thus, is a potentially strong determinant of first impressions. The effect 
is pervasive, occurring in a large array of impression responses from the audience. We assume that the perceivers typically associated attractiveness with other desirable characteristics (e.g., likeableness, social competence) in this context the media personae's charm, likeability and complex dynamics with other characters.

\section{Perceived Similarity Between User and Television Character}

The utterances below clearly state that a majority of online female gaze looks while the male body is looked at; it attempts to show masculine identity cannot be interpreted separately from the image of men projected by, or perceived to be projected by, women.
$P$ There is just something about him...he's charismatic \& its as though his potent magical pheromones penetrate our screens. Makes me feel like a teenager again with a major crush (even when he's in his asshole/bastard mode).
P11: Ladies...I just ordered this jacket cause it reminds me of the one Can had on $\cdot-\cdot \cdot \cdot-2$

Hegemonic ideals of manhood were prominent throughout this analysis. The users also came to know and imaginatively felt that they were interacting with the character Can Divit and they seem to have the feeling that the 'character' would respond back. The users also felt that by copying his style, they would feel some kind of affinity with him.

\section{Perceived Interaction with the Character}

The interactions of the audiences both with the male character and supporting characters in some instances can have a form as if it is face-to-face and primary (Lopata 1965), is not mediative which is one of the main features of parasocial interaction developed with characters represented in the media. It can be seen from the quotations presented below:

\footnotetext{
P9: Note to Can Divit : Please kick out Polen out of your house. We fans are getting agitated that she is tarnishing your cute dimple personality to a mouse.

P10: Mr Can, could you become my trainer? You can scream at me, touch me, punish me, bind me...

P11: Please beat him Can Bey...we would love to see this (referring to the main character and supporting character)
}

It should also be suggested, as can be seen, that the nature of the parasocial interaction with the male character is not never divorced from the hegemonic forms of masculinity.

\section{Sexual Attraction}

At the same time, the comments which sometimes seemed sexual in nature also portrayed the character as a protector, a person who is physically fit, strong and dominating. The majority women audience of this show were driven by the sexual attraction for the character Can Divit. Women seemed to be forward and suggestive in their comments and reiterated that they would leave their realities to be with the character who is fictional.

P19:What comes to my mind and probably to some of you too is ...Because when Can closes his eyes I think SEX. When he opens his eyes, I think SEX. When it rains I think sex with Can and when it stops raining I think Can must be showering obviously naked ...so sex again! In case anybody wonders what do I think when Can or EK are involved. P6:His looks killed the episode. He looks super hot... P12:He 'ooozeeees' Sex with every move he makes!

P18: Can Divit.. I am lonely wanna catch up? 
P19:I am ready to become a loner for him. I have decided to ditch my husband and kids and go to Turkey on my own (Whenever I collect enough money) P20:Lunch is served, Who's hungry???Sidebar: Is it just me or is Can Divit when Angry, Pissed off at Emre, He is Sorta, kinda, ya know, a lil bit, Yassss, Lord have mercy, Tie me up, in some type of way, HOT AF?!!!!!!

All this user generated contents cannot simply be considered as the thoughts of the audiences concerning the protagonist as to how sexy he is. Further, they are the discourses produced by the viewers that constitute the legitimate ground for hegemonic masculinity which defines how a man should be, should look like, and should behave.

\section{Perceived Character as a Friend}

The viewers came to feel that they know the character as a friend as well as they would be neighbor, colleague or their own friend. The users developed an intimate social relationship with the media character Can Divit and expressed their wanting to have or hoped to have a relationship with the character and this was represented through the portrayal of the male character as below:

P12: Can Divit is a professional photographer with a sensitive heart. He is a man of contradictions... His father runs a successful advertising agency but Can prefers to work with human rights associations and NGOs working for refugees. He belongs to the nature.... he doesn't follow the fashion trends, he creates his own brand where he wears whatever he likes disregarding public views...

P14: The scene was so sad. Ifelt Can bey's pain

P16: When you hurt yourself don't go to a doctor. Because Can Bey will do it for you.

While the users were perceived to be interacting with the character, a few users were also defensive of the character Can when others would condemn him which inferred that they did not see Can as a media personae but as one of them.

P64: If I'm sad for Sanem, I'm sad too reading some comments(lol). Please don't treat Can as a cruel person. He was hurt, he is stubborn its true. But in their happy moments, he is kind, attentive, caring for her, funny. He values his work. He is a good person, rather nice and loved by his employees. Don't destroy him.

Some viewers - admitting to being 'feminists' seem to overlook this and embrace the character as 'being alpha male' (the character kidnapped the heroine by carrying her fireman style and placing her in his truck - Ep34) prescribed and justified the action as something that the heroine could do to bring him to the point of sanity and admitted that the character 'was finally ready to talk, to listen, to get it all out on the table. Can, who has to have basic control in his head for any type of clarity'.

In Ep34 also, the male character seem to move out of the traditional form of masculinity. This was mentioned by a viewer who felt that in previous episodes,

Can combated his feelings in what he and we thought was out of pride, out of mucho-ness. But really, the core reason of Can's actions was the fear of getting hurt again. When he completely let go of that fear, he was faced with an even bigger fear- the fear of losing the one thing in his entire world that gives him life. 
This in many ways contradicts the stereotypical masculine traits of egoism, pride and not demonstrating emotions, but the authors believe that the media character navigates his character as hegemonically masculine to the point then even when his character had demonstrated an opposite of dominant masculinity, the viewers were still accepting of his 'maleness' and could not fault him for his need to be 'unmasculine'.

\section{Conclusion}

The purpose of this study was to focus on two important areas, that of parasocial interaction and masculinity which is seen to exist cyclically during the parasocial interaction of viewers with the character. The users are influenced by the media character and by his overarching masculine traits which seem to be very stereotypical. At the same time, because of the male characters authority and screen personae this influences the parasocial interactions of users online. Hegemonic masculinity suggests that masculinity exercises an epistemic authority in modern society and is focused on particular constructions of masculinity shaped by the setting and their social relations as mentioned by Kronsell (2005). The male character in this series clearly was developed as an archetypal male that is heterosexual, operating in a range of actions and commanding authority from other characters around him. It is believed that the hegemonic construction of masculinity was purposely designed to accentuate this male character's dominant position in the series (society).

At the same time, it is clear that the users have built an online community which embraces the characters dominance, authority and 'maleness'. Thus it can be suggested that the women in the study consume the hegemonic ideals of masculinity represented in the series Erkenci Kuş "inside the dominant code" (Hall 2005, 126) and that their pleasure stemming from the consumption of the T.V. content in question is hegemonic pleasure (Fiske 1990, 49). The authors identified that the users online were engaging and interacting with the show and with other online users using the male character as the focal point of discussion. Our results provide support for the assertions of Gunter and Wober (1982) that the construction of this character upholds sex role and trait stereotyping and concurs with Earp et al. (1999) that there still exists the portrayal of media characters that reinforce male social dominance. This in turn seems to attract 'female gaze' which seems voyeuristic in nature. Hegemonic masculinity nevertheless can be seen to be changing and revolving. To retain its privileged position, it must adjust to meet contemporary society's demands and to avoid the threat posed by an increasingly powerful and outspoken transnational online community made up of a majority of women. These adaptations include the feminization of masculinities as mentioned by Barthel (1994) as men are encouraged to engage in the consumption, to be concerned with their appearance, to be engaging with their emotions and as male bodies are objects of display subject to the female gaze.

We noted that the Turkish series sexualizes the male body and Can Divit is being characterized as the epitome of the 'real man'. That being said, there seem to be a progress in the way certain traits are being incorporated such as the showing of emotion and the more gentle natured characteristics which is deemed peculiar to hyper masculinity or hegemonic masculinity. The perception that attractive individuals elicit positive reactions from others and the media portrayal of attractiveness as critical to heterosexual popularity and social attention is clearly defined in this study.

Our current analysis also did not consider the cultural aspect of how Turkish men are particularly depicted or the extent in which certain traits may be exclusive to the region in question. Future research may include the uniqueness of culture and in-depth interviews may be applicable to understand the mindset of the users. The need for an experimental study to 
consider views of those who have not viewed the series or the audience being all male may project an interesting and unique take on the perception of masculinity and masculine traits.

Media representations of the male character on television has changed over time. With women coming to the forefront of characterization, men are slowly being evolved in the media to include different forms of masculinity such as metrosexuality in terms of grooming, fashion and aesthetics. Care, nurturing and being emotional is understood as a part of masculinity today and confers a model that rejects patronizing and overprotecting and instead emphasizes dignity and social identity through humor, complicity, and activities outside the domestic space. Nevertheless, hyper masculinity and hegemonic masculinity remain dominant due to its malleability, to mold itself into emerging or new forms of masculinity. The image of women being objectified through the 'male gaze' has always been common, but in this context it is clear that men can also be objectified through portrayals in the media and popular culture. However, it should be considered that this argument always stands on a slippery slope since while women can occupy a position through where they can be the actors of the 'gaze' and thus can have empowering experiences (Fiske 1990), this position itself can provide a space in which hegemonic ideals might be maintained.

This paper has provided an idea as to how parasocial interaction might be used to understand online communities who gravitate towards male characters who dominate the screen with hyper masculine traits which are hegemonic in nature.

\section{REFERENCES}

Alperstein N. (1991). "Imaginary social relationships with celebrities appearing in television commercials". Journal of Broadcasting and Electronic Media 35 (1991) 43-58.

Armstrong N., Koteyko N. \& Powell J. (2012). “'Oh dear, should I really be saying that on here?’: Issues of identity and authority in an online diabetes community". Health 16/4 (2012) 347-365.

Araüna N., Tortajada I. \& Willem C. M. (2018). "Portrayals of Caring Masculinities in Fiction Film: The Male Caregiver in Still Mine, Intouchables and Nebraska". Masculinities \& Social Change 7/1 (2018) 82-102.

Barthel D. (1990). "A Consumer and a Gentleman". Public Culture 2/2 (1990) 129-134.

Baym N. K. (2007). The new shape of online community: The example of Swedish independent music fandom. First Monday, Retrieved from https://firstmonday.org/ojs/index.php/fm/article/view/1978/1853.

Benecchi E. (2015). "Online Italian fandoms of American television shows". Ed. Anne Kustritz, special issue, Transformative Works \& Cultures 19 (2015) https://doi.org/10.3983/twc.2015.0586

Benecchi E. \& Richeri G. (2013). "TV to talk about: engaging with American television series through the internet". Eds. Alberto Abruzzese \& Nello Barile. The New Television Ecosystem (2013) 121-140 Bern.

Berger P. L. \& Luckmann T. (1991). The social construction of reality: A treatise in the sociology of knowledge (No. 10). London 1991.

Bernard H. R. (1994). Research methods in anthropology: Qualitative and quantitative approaches. Thousand Oaks 1994.

Braun V. \& Clarke V. (2014). "What can "thematic analysis" offer health and wellbeing researchers?". International journal of qualitative studies on health and well-being 9/26152 (2014) doi:10.3402/qhw.v9.26152

Carroll N. (1996). Theorizing the Moving Image. Cambridge 1996.

Cole T. \& Leets L. (1999). "Attachment styles and intimate television viewing: Insecurely forming relationships in a parasocial way". Journal of Social and Personal Relationships 16/4 (1999) 495-511.

Connell R. W. (2005). Masculinities. Berkeley 2005.

Connell R. W. \& Messerschmidt J. W. (2005). "Hegemonic Masculinity: Rethinking the Concept". Gender \& Society 19/6 (2005) 829-859.

Connell, R. W. (1992). “A Very Straight Gay: Masculinity, Homosexual Experience, and The Dynamics of Gender". American Sociological Review 57/6 (1992) 735-751.

Coston B. M. \& Kimmel M. (2012). “Seeing privilege where it isn't: Marginalized masculinities and the 
intersectionality of privilege". Journal of Social Issues 68/1 (2012) 97-111.

Creeber G. (2001). "Taking Our Personal Lives Seriously: Intimacy, Continuity and Memory in the Television Drama Serial”. Media, Culture \& Society 23/4 (2001) 439-455.

Cresswell J. W. (2014). Research Design: Qualitative, Quantitative, and Mixed Methods Approaches. Los Angeles 2014.

Donaldson, M. (1993). "What is Hegemonic Masculinity”. Theory and Society 22/5 (1993) 643 - 657.

Driesmans K., Vandenbosch L. \& Eggermont S. (2016). "True love lasts forever: The influence of a popular teenage movie on Belgian girls' romantic beliefs". Journal of Children and Media 10 (2016) 304-320

Earp J., Jackson K. (writers) \& Jhally S. (producer and director). (1999). Tough Guise: Violence, Media \& the Crisis in Masculinity. Media Education Foundation 1999.

Ergur, A. (2016). "Enformasyın Çağında Yabancılaşma, Ă̆ Toplumunda Anomi: Yeni Hakikat Rejimi ve Bölünmüş Gerçeklik Deneyimi”. Ed. Ali Ergur. Buruk Şenlik: Enformasyon Toplumundan Anomi ve Yabancılaşmanın Yeni Biçimleri. Ankara (2016) 17-57.

Erickson S. E. \& Cin S. D. (2018). "Romantic parasocial attachments and the development of romantic scripts, schemas and beliefs among adolescents". Media Psychology 21/1 (2018) 111-136.

Fiske J. (1990). Understanding Popular Culture. London 1990.

Giles D. C. (2002). "Parasocial interaction: A review of the literature and a model for future research". Media psychology 4/3 (2002) 279-305.

Giles D. C. \& Maltby J. (2004). "The role of media figures in adolescent development: relations between autonomy, attachment: and interest in celebrities". Personality and Individual Differences 36 (2004) $813-822$.

Gill R., Henwood K. \& McLean C. (2005). "Body Projects and the Regulation of Normative Masculinity". Body \& Society 11/1 (2005) 37-62.

Gunter B. \& Wober M. (1983). Violence on television: What the viewers think. London 1983.

Gürkan H. \& Serttaş A. (2017). "The Representation of Masculinity in Cinema and on Television: An Analysis of Fictional Male Characters". European Journal of Multidisciplinary Studies 5/1 (2017) 402-408.

Hall S. (2005). "Encoding/decoding”. Eds. Stuart Hall; Dorothy Hobson; Andrew Lowe \& Paul Willis. Culture, Media, Language. London (2005) 117-128.

Hobson D. (2003). Soap Opera. Cambridge 2003.

Hobson D. (1982). Crossroads: the Drama of a Soap Opera. London 1982.

Hobson D. (1989). "Soap Operas at Work". Ed. Ellen Seiter. Remote Control: Television. Audiences and Cultural Power. London (1989) 150-167.

İnceoğlu Y. \& Akçalı E. (2018). Televizyon Dizilerinde Toplumsal Cinsiyet Eşitliği Araştırması, TÜSİAD Televizyon Dizilerinde Toplumsal Cinsiyet Eşitliği Projesi. TÜSİAD 2018.

Ingram J. \& Luckett Z. (2017). "My Friend Harry’s a Wizard: Predicting Parasocial Interaction With Characters From Fiction". Psychology of Popular Media Culture 8/2 (2017) 148-158.

Irani, D. 2017. Here's why Turkish soaps are a cultural force to be reckon with. Retrieved from https://economictimes.indiatimes.com/heres-why-turkish-soaps-are-a-cultural-force-to-reckonwith/articleshow $/ 57289530 . \mathrm{cms}$ ?from $=\mathrm{mdr}$.

Jenkins H. (2006). Convergence culture: Where new and old media collide. New York 2006.

Jenkins H., Ford S. \& Green J. (2013). Spreadable media: Creating value and meaning in a networked culture. New York 2013.

Kimmel, M. (1994). "Masculinity as homophobia: fear, shame, and silence in the construction of gender identity". Eds. Harry Brod \& Michael Kaufman. Research on men and Masculinities Series: Theorizing masculinities. Thousand Oaks (1994) 119-141.

Kincaid D. L. (2002). "Drama, Emotion, and Cultural Convergence". Communication Theory 12/2 (2002) 136-152.

Kronsell A. (2005). "Gendered practices in institutions of hegemonic masculinity: Reflections from feminist standpoint theory". International Feminist Journal of Politics 7/2 (2005) 280-298.

LeCompte M. D. \& Schensul J. J. (1999). Designing and conducting ethnographic research (Vol. 1). Lanham 2005.

Liebes T. \& Katz E. (1990). The export of meaning: Cross-cultural readings of “Dallas”. New York 1990.

Liu, L. (2016). Using Generic Inductive Approach in Qualitative Educational Research: A Case Study Analysis. Journal of Education and Learning 5/2 (2016) 129-135. 
Lopata, H. Z. (1965). "The Secondary Features of a Primary Relationship". Society for Applied Anthropology 24/2 (1965) 116-123.

Morgan D. (1993). "You too can have a body like mine: reflections on the male body and masculinities". Ed. Sue Scott \& David Morgan. Body matters: Essays on the sociology of the body. London (1993) 70-90.

Neville P. (2009). "Side-splitting masculinity: comedy, Mr Bean and the representation of masculinities in contemporary society". Journal of gender studies 18/3 (2009) 231-243.

Newcomb H. (1974). Television: The Most Popular Art. New York 1974.

Noble G. (1975). Children in front of the small screen. Beverly Hills 1975.

Pérez-Gil M. D. M. (2019). "Representations of Nation and Spanish Masculinity in Popular Romance Novels: The Alpha Male as “Other". The Journal of Men's Studies 27/2 (2019) 169-182.

Rambe P. (2012). "Critical discourse analysis of collaborative engagement in Facebook postings". Australasian Journal of Educational Technology 28/2 (2012) 295 - 314.

Ricciardelli R. \& Clow K. A. (2013). "The portrayal of elements historically associated with masculine and feminine domains in lad and metrosexual men's lifestyle magazines". Masculinities and Social Change 2/2 (2013) 116-145.

Riley R., Baker D. \& Van Doren C. (1998). "Movie-induced tourism”. Annals of Tourism Research 25/4 (1998) 919-935.

Rodriguez N. S., Huemmer J. \& Blumell L. (2016). "Mobile masculinities: An investigation of networked masculinities in gay dating apps". Masculinities and Social Change 5/3 (2016) 241-267.

Rubin A. M., Perse E. M. \& Powell R. A. (1985). "Loneliness, parasocial interaction, and local television news viewing". Human Communication Research 12 (1985) 155-180.

Scharrer E. \& Blackburn G. (2018). "Cultivating conceptions of masculinity: Television and perceptions of masculine gender role norms". Mass Communication and Society 21/2 (2018) 149-177.

Schmid H. \& Klimmt C. (2011). “A magically nice guy: Parasocial relationships with Harry Potter across different cultures”. International Communication Gazette 73 (2011) 252-269.

Smedley R. M. \& Coulson N. S. (2018). "A practical guide to analysing online support forums". Qualitative Research in Psychology (2018) DOI: 10.1080/14780887.2018.1475532

Stibbe A. (2004). "Health and the social construction of masculinity in Men's Health magazine". Men and Masculinities 7/1 (2004) 31-51.

Storey J. (2014). From Popular Culture to Everyday Life. London 2014.

Sutton J., Palen L. \& Shklovski I. (2008). Backchannels on the Front Lines: Emergent Uses of Social Media in the 2007 Southern California Wildfires. Proceedings of the 5th International ISCRAM Conference.

Thomas, D. (2006). A General Inductive Approach for Analyzing Qualitative Evaluation Data. American Journal of Evaluation. 27, 237-246. http://dx.doi.org/10.1177/1098214005283748

Tian Q. \& Hoffner C. A. (2010). "Parasocial interaction with liked, neutral, and disliked characters on a popular television series". Mass Communication and Society 13/3 (2010) 250-269.

Tukachinsky R. (2010). "Para-romantic love and para-friendships: Development and assessment of a multiple-parasocial relationships scale". American Journal of Media Psychology 3/1/2 (2010) 73-94.

Valaskivi K. (2000). "Being a part of the family? Genre, gender and production in a Japanese television drama. Media". Culture \& Society 22/3 (2000) 309-325.

Vassallo de Lopes M. I. (2012). A case study on transmedia reception: Fandom on Facebook and social issues in the brazilian telenovela Passione. Anàlisi: quaderns de comunicació i cultura. (2012) 111-132.

Yücel V. (2014). Kahramanın Yolculuğu: Mitik Erkeklik ve Suç Draması. İstanbul 2014.

Zrebiec J. F. \& Jacobson A. M. (2001). "What attracts patients with diabetes to an internet support group? A 21-month longitudinal website study”. Diabetic medicine 18/2 (2001) 154-158. 